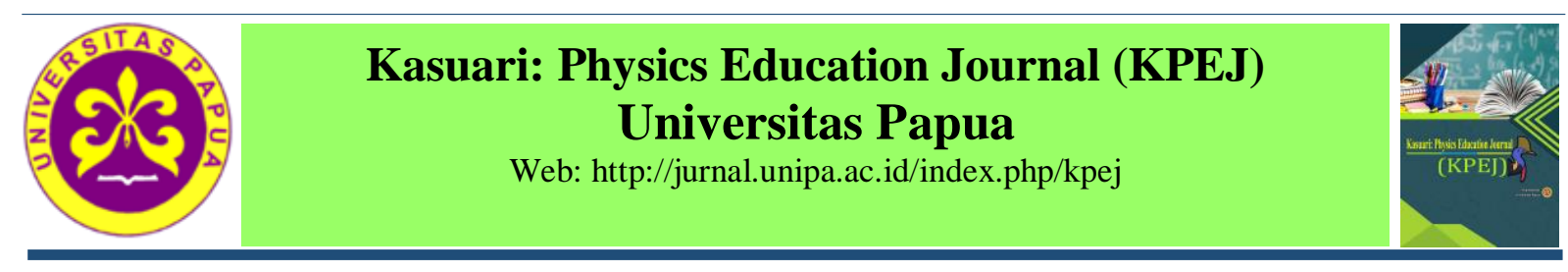

\title{
Improving Students Learning Result Through Coorperative Type SAVI
}

\author{
Tiadsen Loupatty*, Mujasam, Sri Rosepda Br. Sebayang \\ Prodi Pendidikan Fisika, Fakultas Keguruan dan Ilmu Pendidikan, Universitas Papua \\ *tiadsenl@gmail.com
}

\begin{abstract}
This research aims to find out how the application of cooperative model in SAVI type to increase students' result of learning in the class XI IPA SMA Adventist Manokwari, so that in the process of learning physics, students have a good value and they do not think that physics is a very difficult lesson. The instrument used is an assignment test for cognitive measures and LKPD for psychomotor measures. This research using the Classroom Action Research method (CAR). The results of this research indicate that, in cycle I the total cognitive value of each student 83 with 100\% classical completeness, and the total psychomotor value of students 93 with 100\% classical completeness. Cycle II the total cognitive value 88 with $100 \%$ classical completeness, and the psychomotor 94 with 100\% classical completeness. This shows that, learners learn to increase.
\end{abstract}

Keywords: learning outcomes, kooperative type SAVI, and PTK

\section{Peningkatan Hasil Belajar Peserta Didik Melalui Penerapan Model Kooperatif Tipe SAVI}

\begin{abstract}
Abstrak: Penelitian ini bertujuan untuk mengetahui bagaimana penerapan model kooperatif tipe SAVI untuk meningkatkan hasil belajar peserta didik di kelas XI IPA 1 SMA Advent Manokwari, sehingga dalam proses pembelajaran fisika peserta didik memiliki nilai yang bagus dan tidak lagi menganggap fisika itu pelajaran yang sangat susah. Instrumen yang digunakan adalah tes penugasan untuk mengukur kognitif dan LKPD untuk mengukur psikomotorik. Penelitan ini menggunakan metode Penelitian Tindakan Kelas (PTK). Hasil dari penelitian ini menunjukkan bahwa, pada siklus I nilai total kognitif pada masing-masing peserta didik 83 dengan ketuntasan klasikal 100\%, dan psikomotorik nilai total peserta didik 93 dengan ketuntasan klasikal 100\%. Siklus II nilai total kognitif 88 dengan ketuntasan klasikal 100\%, dan psikomotorik 94 dengan ketuntasan klasikal 100\%. Hal ini menunjukan bahwa, hasil belajar peserta didik meningkat.
\end{abstract}

Kata Kunci: hasil belajar, kooperatif tipe SAVI, dan PTK

\section{PENDAHULUAN}

Sains merupakan ilmu pengetahuan yang memperlajari gejala-gejala yang terjadi di alam, sehingga menghasilkan produk ilmiah yang tersusun atas tiga komponen terpenting berupa teori, prinsip, dan konsep Pratama (2015: 6). Kemampuan sains sangatlah penting dimiliki oleh peserta didik, karena peserta didik dilatih untuk berpikir secara baik dalam memecahkan suatu permasalahan, khususnya pada mata pelajaran fisika.

Fisika merupakan salah satu bagian dari sains, yaitu ilmu yang mempelajari tentang sifat serta gejala-gejala yang terjadi di alam. Hamid (2011: 19) menjelaskan bahwa, tujuan dari peserta didik mempelajari fisika yaitu: 1) mengetahui keadaan alam, sehingga manusia memiliki keyakinan dan kepercayaan terhadap Tuhan Yang Maha Kuasa akan semakin meningkat; dan 2) meningkatkan kemampuan dan sikap ilmiah. 
Fisika bisa dikatakan salah satu pelajaran yang sangat asik, dikarenakan fisika mengajarkan bagaimana untuk lebih memahami fenomena yang terjadi di lingkungan. Maka peserta didik diharapkan untuk sungguh-sungguh dalam belajar fisika, guna menambah wawasan peserta didik tentang fenomena-fenomena yang terjadi di alam sekitarnya. Pembelajaran fisika adalah salah satu bagian dari sains yang diajarkan di sekolah, dalam pembelajaran fisika terdapat kegiatan yang mengajak peserta didik untuk memahami fisika melalui interaksi pengajaran atau proses belajar mengajar (PBM) Lesmono (2012: 286). Proses pembelajaran fisika memfokuskan pada pengalaman langsung yang dialami oleh peserta didik untuk mengembangkan kemampuan dalam meneliti dan memahami alam sekitar secara ilmiah Lesmono (2012: 286). Oleh karena itu, pembelajaran fisika pada SMA Advent kelas XI IPA harus menekankan pada keaktifan dan berbaur dengan alam, sehingga peserta didik menyukai dan lebih giat lagi dalam mempelajari fisika dan dapat meningkatkan hasil belajar fisika.

Hasil belajar adalah pengetahuan dan prestasi yang telah dicapai pada pelajaran tertentu, namun dalam mengukur keberhasilan peserta didik harus menggunakan standar sebagai tolak ukur keberhasilannya Pamelang (2012: 9). Berdasarkan penjelasan tersebut, dapat disimpulkan bahwa hasil belajar adalah potensi yang dimiliki oleh pelajar, melalui pengalaman belajar yang ditempuhnya. Tinggi rendahnya hasil belajar dipengaruhi oleh beberapa hal, diantaranya adalah kegiatan pembelajaran yang masih berpusat kepada pendidik serta penyampaian materi yang kurang menarik (Hayandani, dkk, 2017: 48). Oleh karenanya, pendidik diharapkan mampu menerapkan metode dan strategi dengan penuh tanggung jawab agar peserta didik mencapai keberhasilan dalam pembelajaran.

Berdasarkan informasi yang peneliti dapatkan melalui hasil wawancara (guru dan peserta didik) dan dokumen atau arsip (ulangan harian peserta didik), bahwa dalam proses pembelajaran ternyata hasil belajar fisika cukup rendah 15 peserta didik dari 22 dalam kelas XI IPA tidak menyukai pembelajaran fisika. Hal ini dipengaruhi oleh beberapa hal, yaitu: 1) sebagian besar peserta didik memiliki kemampuan matematika dasar rendah; 2) penggunaan media pembelajaran oleh guru kurang bervariasi; 3 ) peserta didik tidak aktif; dan 4) guru menggunakan metode ceramah, mengakibatkan suasana belajar yang berlangsung cenderung pasif. Sehingga mengakibatkan $90 \%$ peserta didik memiliki nilai di bawah KKM, yaitu 70. Oleh karena itu, peneliti ingin melihat dan mengetahui bagaimana penerapan model kooperatif tipe SAVI untuk meningkatkan hasil belajar peserta didik di kelas XI IPA SMA Advent Manokwari.

Kooperatif adalah model pembelajaran yang dibagi dalam kelompok-kelompok kecil, dimana guru sebagai vasilitator selama berlangsungnya pembelajaran Jamal (2013: 160). Pembelajaran kooperatif merupakan pembelajaran yang dirancang sebaik mungkin oleh guru untuk meningkatkan kemampuan kepemimpinan peserta didik, penerimaan terhadap keragaman peserta didik, meningkatnya kemampuan akademik, dan pengembangan kemampuan sosial Jamal (2013: 161). Model pembelajaran kooperatif memiliki salah satu dari tipenya, yaitu pembelajaran model kooperatif tipe Somatic, Auditory, Visual, and Intellectual (SAVI) adalah suatu pembelajaran yang melibatkan kemampuan mengerjakan dan bergerak, mendengar dan berbicara, memperhatikan dengan teliti dan menggambar, serta memecahkan masalah.

Berdasarkan beberapa penelitian yang dilakukan dengan menerapkan model kooperatif tipe SAVI diperoleh hasil belajar yang baik. Seperti halnya penelitian yang dilakukan oleh Fitriyaningsih (2013), dalam hasil penelitiannya yang menyatakan bahwa, dengan adanya penerapan model pembelajaran kooperatif tipe SAVI, bisa membantu peserta didik dalam memahami materi fisika, sehingga hasil belajar peserta didik meningkat. 


\section{METODE PENELITIAN}

Metode penelitian ini merupakan Penelitian Tindakan Kelas (PTK). Penelitian ini bertujuan untuk mengetahui peningkatan hasil belajar peserta didik melalui penerapan model kooperatif tipe SAVI di kelas XI IPA SMA Advent Manokwari. Selama penelitian berlangsung, dilakukan dalam 2 siklus, dimana masing-masing siklus terdiri dari 2 pertemuan. Pengambilan data dilaksanakan pada bulan Februari sampai April 2018, semester genap tahun ajaran 2018/2019. Subjek penelitian adalah peserta didik di kelas XI IPA SMA Advent Manokwari, dengan jumlah peserta didik 22. Namun, yang diambil hanya peserta didik yang selalu hadir disetiap pertemuan pada masing-masing siklus, yaitu 11 peserta didik. Proses pembelajaran dalam setiap pertemuan, dilaksanakn dengan alokasi waktu 2 x 45 menit. Teknik pengumpulan data yang digunakan dalam penelitian ini, yaitu observasi, dokumentasi dan tes penugasan essay. Instrumen yang digunakan dalam penelitian ini adalah Rencana Pelaksanaan Pembelajaran (RPP), lembar soal tes penugasan essay untuk mengukur hasil kognitif dan LKPD yang dibantu dengan rubrik penilaian untuk mengukur hasil psikomotorik. Validasi lembar soal tes penugasan essay dan LKPD yang dibantu dengan rubrik penilaian psikomotorik, sebelum diterapkan peneliti ujikan terlebih dahulu ke peserta didik kelas XII untuk memperoleh nilai validasi item, dapat ditentukan dengan kriteria berikut: Nilai Outfit Mean Square (MNSQ) yang baik memiliki syarat yaitu $0,5<\mathrm{MNSQ}<1,5$. Nilai Outfit Z-standar (ZSTD) yang diterima adalah $-2<\mathrm{ZSTD}<+2$. Nilai Poin Measure Correlation (Pt Mean Corr) yang diterima adalah 0,4<Pt Mean Corr $<0,85$ (Sumintono dan Widhiarso, 2015: 103).

Reliabilitas instrumen diperoleh berdasarkan hasil dari validasi instrumen. Nilai reliabilitas butir soal tes penugasan essay dan rubrik psikomotorik, dapat dilihat menggunakan aplikasi winstep pada bagian summary statistic yang berpedoman pada kriteria Sumintono dan Widhiarso (2015: 109), yaitu:

Tabel 1. Nilai Reliabilitas

\begin{tabular}{|c|c|c|}
\hline No & Rentang & Kategori \\
\hline 1 & $<0,67$ & Lemah \\
\hline 2 & $0,67-0,80$ & Cukup \\
\hline 3 & $0,80-0,90$ & Bagus \\
\hline 4 & $0,90-0,94$ & Bagus Sekali \\
\hline 5 & $>0,94$ & Istimewa \\
\hline
\end{tabular}

Teknik analisis data secara umum yang digunakan dalam penelitian ini adalah Rasch Model dengan tipe (Winstep dan Facets) dan exel. Ketika semua data telah terkumpul peneliti bisa cantumkan dalam Statistik deskritif dan analisis kualitatif yang bertujuan untuk melihat sejauh mana tingkat keberhasilan dalam penelitian, sehingga peneliti dapat menarik kesimpulan selama penelitian berlangsung.

Pengkategorian hasil belajar peserta didik pada siklus dapat dilihat berdasarkan kriteria Tabel 2 (Riduwan, 2011: 41).

Tabel 2. Kategori hasil belajar peserta didik setiap siklus

\begin{tabular}{|c|c|}
\hline Skala & Kategori \\
\hline $0-20$ & Sangat Kurang \\
\hline $21-40$ & Kurang \\
\hline $41-60$ & Cukup \\
\hline $61-80$ & Baik \\
\hline $81-100$ & Sangat Baik \\
\hline
\end{tabular}


Berdasarkan kriteria validitas dan reliabilitas di atas, peneliti mengelolah instrumen (RPP, LKPD, dan lembar tes penugasan) menggunakan Facets dan Winstep, hasil yang diperoleh adalah valid. Sehingga instrumen yang digunakan dapat diterapkan di kelas penelitian.

\section{HASIL DAN PEMBAHASAN}

\section{Hasil Belajar Kognitif}

Berdasarkan hasil penelitian penerapan model kooperatif tipe SAVI, di kelas XI IPA SMA Advent Manokwari, ternyata hasil belajar kognitif peserta didik telah meningkat. Meningkatnya hasil belajar peserta didik, didukung olehnya adanya penerapan model kooperatif tipe SAVI dengan beberapa karakteristik pada SAVI, yaitu Somatic (gerakan tubuh), Auditory (mendengar), Visual (menggambar), dan Intellectual (kecerdasan) Wijayanti (2013: 3) dan Sari (2017: 109).

Karakteristik dari model kooperatif tipe SAVI terlihat jika peneliti memulai proses pembelajaran. Somatic (gerakan tubuh) terlihat saat peserta didik berdiskusi dalam mengerjakan soal latihan yang diberikan oleh peneliti. Auditory (mendengar) terlihat saat peserta didik memperhatikan apa yang disampaikan oleh peneliti dan menanyakan beberapa pertanyaan. Visual (menggambar) terlihat jika peneliti memberikan persoalan kepada peserta didik, mengenai apa yang dipelajarinya. Maka ada beberapa peserta didik yang mencoba untuk menjelaskan persoalan tersebut dengan teori dan didukung oleh gambar. Intellectual (kecerdasan) terlihat saat peserta didik menjawab soal yang diberikan oleh peneliti.

Fenomena ini sejalan dengan Armawati (2014: 121) yang menyatakan bahwa karakteristik dari model pembelajaran akan terlihat jika adanya rangsangan yang dilakukan oleh guru kepada peserta didik. Berdasarkan penjelasan tersebut, berikut ini hasil belajar peserta didik pada siklus I dan siklus II dapat dilihat pada Gambar 1, yaitu:

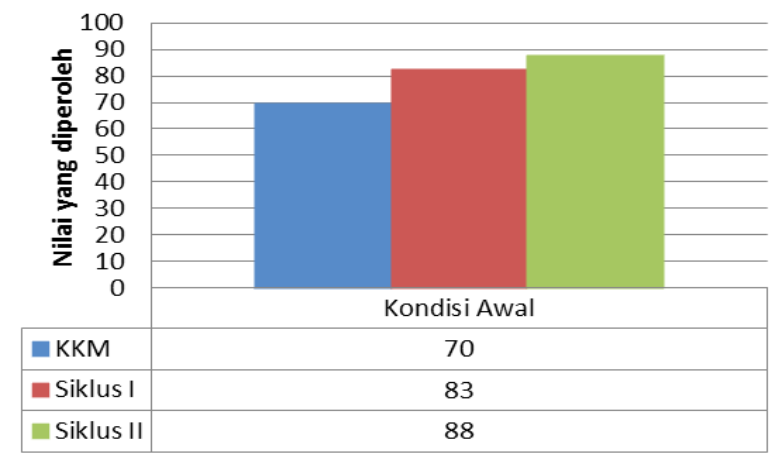

Gambar 1. Peningkatan KKM kognitif

Gambar 1 menunjukkan bahwa, siklus I pada aspek kognitif mengalami ketuntasan hasil belajar peserta didik meningkat menjadi 83. Walaupun ketuntasan hasil belajar peserta didik sangatlah meningkat pada siklus I, peneliti tetap akan melanjutkan ke siklus II. Hal ini bertujuan untuk melakukan perbandingan dan memperbaiki kekurangan pada siklus I.

Perbaikan yang dilakukan pada siklus II guna untuk melengkapi kekurangan siklus I. Siklus II, setelah dilakukan beberapa tindakan perbaikan, maka diperolehlah ketuntasan hasil belajar peserta didik mencapai 88. Fenomena ini sejalan dengan Valia (2015: 368369) yang menyatakan bahwa hasil belajar peserta didik mengalami peningkatan apa bila adanya perbaikan pada model dan strategi pembelajaran. Hal ini, kita bisa lihat lebih terperinci lagi pada Gambar 2. 


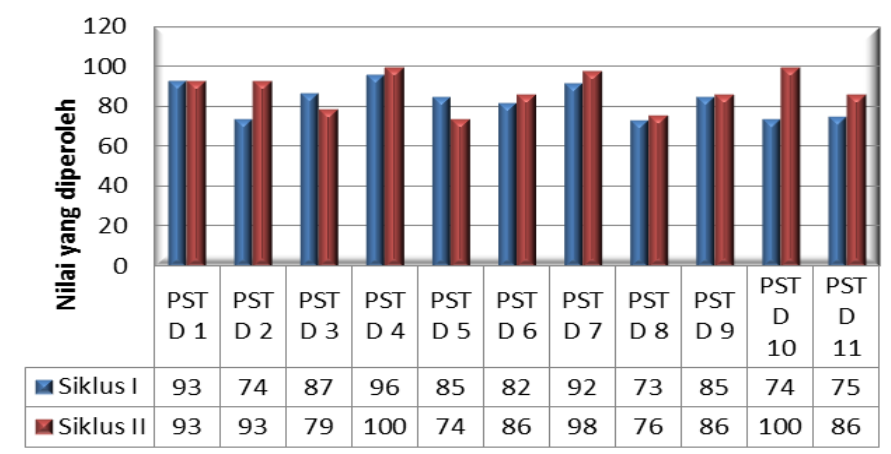

Gambar 2. Peningkatan hasil belajar kognitif

Gambar 2 menunjukkan bahwa pada siklus I peserta didik memiliki nilai tertinggi adalah 93, sedangkan nilai terendah adalah 73. Rendahnya nilai peserta didik diakibatkan peserta didik memiliki kemampuan dalam pengoperasian angka masih kurang baik, sehingga peserta didik harus membutuhkan bimbingan yang lebih khusus lagi oleh peneliti.

Siklus II peserta didik memiliki nilai tertinggi adalah 100 dan terendah adalah 74 . Rendahnya hasil belajar peserta didik masih diakibatkan adanya kesalahan dalam pengoperasian angka, sehingga waktu yang digunakan untuk mengerjakan tes penugasan essay belum cukup. Fenomena penelitian ini sejalan dengan hasil penelitian oleh Fitriyaningsih (2013: 5) yang menyatakan bahwa hasil belajar kognitif peserta didik meningkat dikarenakan peserta didik sangat aktif dan termotivasi terhadap mata pelajaran fisika.

\section{Hasil Belajar Psikomotorik}

Berdasarkan hasil penelitian penerapan model kooperatif tipe SAVI, di kelas XI IPA SMA Advent Manokwari, ternyata hasil belajar psikomotorik peserta didik telah meningkat. Meningkatnya hasil belajar peserta didik, didukung olehnya adanya penerapan model kooperatif tipe SAVI dengan beberapa karakteristik pada SAVI, yaitu Somatic (gerakan tubuh), Auditory (mendengar), Visual (menggambar), dan Intellectual (kecerdasan).

Karakteristik dari Model Kooperatif tipe SAVI terlihat jika peneliti memulai proses pembelajaran. Somatic (gerakan tubuh) terlihat jika peserta didik seacara berkelompok mencoba untuk memperagakan media pembelajaran dan saling berdiskusi. Auditory (mendengar) terlihat jika peserta didik mendengarkan peneliti dalam menjelaskan langkah-langkah bagaimana menjawab LKDP. Visual (menggambar) terlihat jika peserta didik mencoba mengerjakan LKPD berdasarkan, informasi dan gambaran yang diberikan oleh peneliti. Intellectual (kecerdasan) terlihat saat peserta didik menjawab LKPD dengan kecerdasan yang dimilikinya. Fenomena ini sejalan dengan Suarjana (2014) yang menyatakan bahwa tindakan dari karakteristik SAVI dapat meningkatkan hasil belajar peserta didik.

Penilaian hasil belajar psikomotorik peserta didik terbagi atas 3 Aspek dan 3 keterampilan, yaitu: P1 (meniru) dengan keterampilan mengambil alat dan bahan, P2 (menggunakan) dengan keterampilan persiapan kelompok, dan P3 (ketepatan) dengan keterampilan kinerja kelompok. Masing-masing keterampilan peneliti memberikan skor maksimum 4 dan skor terendah 1. Penilaian psikomotorik peneliti hanya berfokus pada keterampilan peserta didik saja, yaitu: a) mengambil alat dan bahan; b) persiapan kelompok; c) kinerja kelompok. Nilai yang diperoleh dalam bentuk kelompok dan akan diolah menjadi nilai masing-masing individu.. Hal ini dapat dilihat pada gambar 3. 
Gambar 3. Peningkatan hasil belajar psikomotorik RPP 1 siklus I

Gambar 3 menjelaskan tentang sebaran kemampuan dari 11 peserta didik dan sebaran tingkat kesukaran soal. Peserta didik 01P, 02P, 03P, 04L, 05L, 06 07L, 08L, 09L, 10L, dan $11 \mathrm{~L}$ adalah peserta didik yang memiliki kemampuan yang tinggi. Kemampuan yang tinggi ditandai dengan logit yang lebih dari 0 . Gambar 3 juga menjelaskan bahwa indikator P2 memiliki tingkat kesukaran yang tinggi, yaitu memiliki logit +1 . Indikator ini menunjukkan bahwa 11 peserta didik belum bisa memperoleh nilai yang maksimal. Indikator P1 dan P3 memiliki tingkat kesukaran yang rendah, yaitu memiliki logit -1 yang artinya 11 peserta didik bisa memperoleh nilai tertinggi.

1

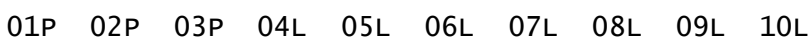

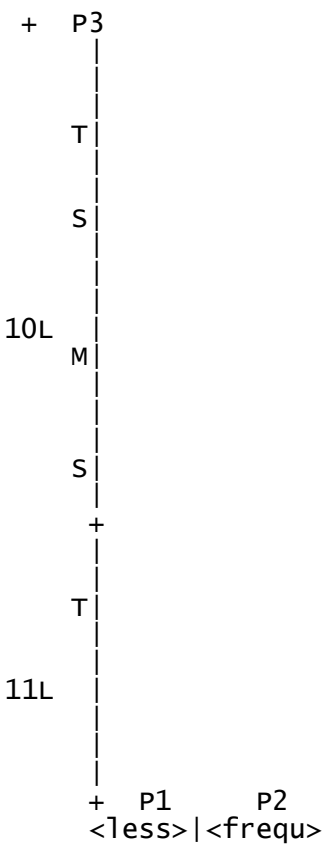

Gambar 4. Peningkatan hasil belajar psikomotorik RPP II siklus I 
Gambar 4 menjelaskan bahwa Peserta didik 01P, 02P, 03P, 04L, 05L, 06 07L, 08L, 09L, 10L, dan 11L adalah peserta didik yang memiliki kemampuan yang tinggi. Kemampuan yang tinggi ditandai dengan logit yang lebih dari 0 . Gambar 4 juga menjelaskan bahwa indikator P3 memiliki tingkat kesukaran yang tinggi, yaitu memiliki logit +1 . Indikator ini menunjukkan bahwa 11 peserta didik belum bisa memperoleh nilai yang maksimal. Indikator P1 dan P2 memiliki tingkat kesukaran yang rendah, yaitu memiliki logit -1 yang artinya 11 peserta didik bisa memperoleh nilai tertinggi.

Berdasarkan Gambar 3 dan Gambar 4, maka peneliti simpulkan bahwa dari 11 peserta didik di kelas XI IPA SMA Advent memiliki kemampuan psikomotorik di atas rata-rata. Fenomena ini sejalan dengan Sari (2015: 573) menyatakan bahwa hasil belajar peserta didik akan meningkat apabila proses pembelajaran yang berbentuk kelompok heterogen dengan memberikan masalah melalui percobaan sederhana, sehingga peserta didik lebih mengetahui proses terjadinya sesuatu.

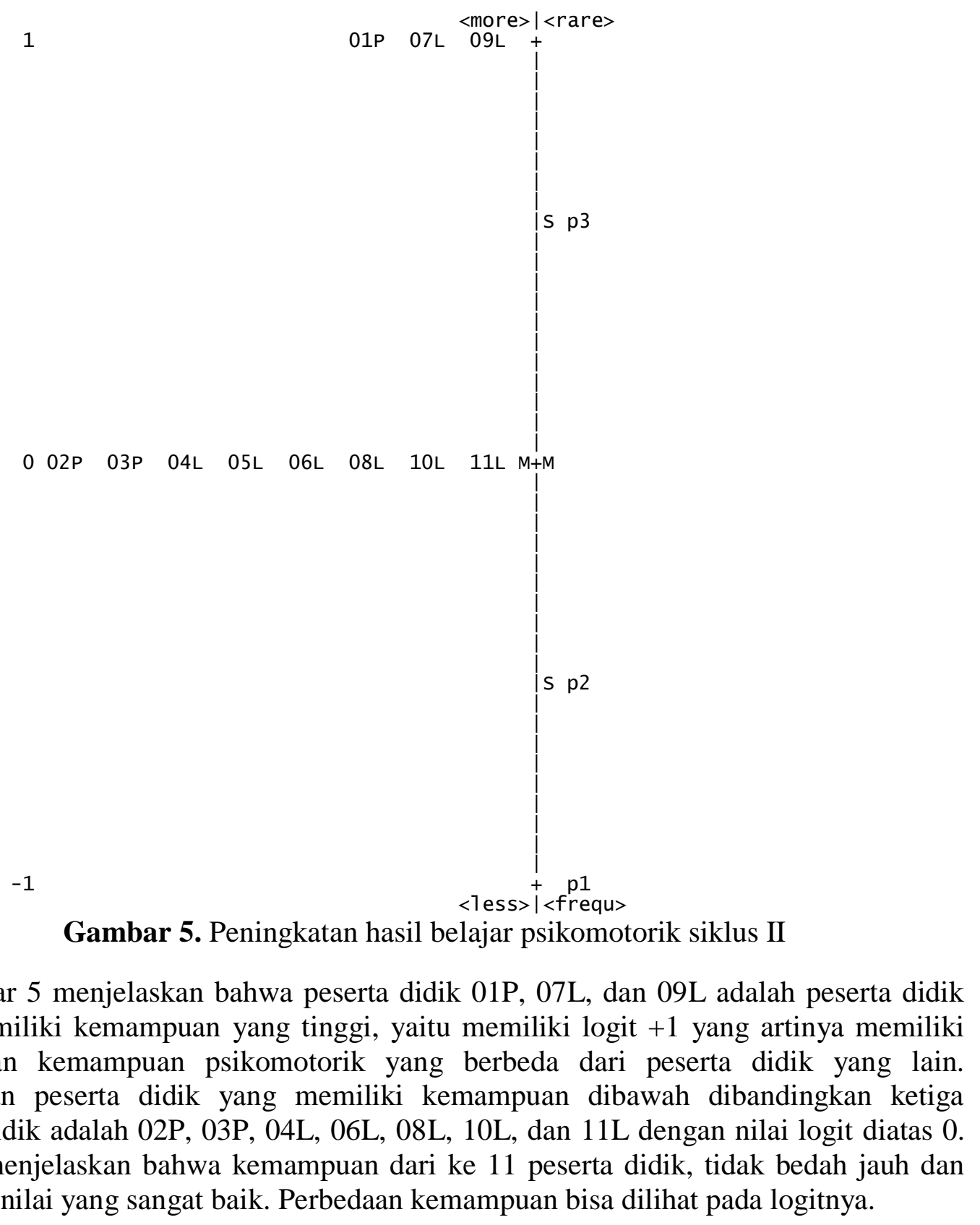


Gambar 5 juga menjelaskan bahwa indikator P3 memiliki tingkat kesukaran yang tinggi, yaitu memiliki logit diatas 0. Indikator ini menunjukkan bahwa, hanya 3 peserta didik yang bisa memperoleh nilai maksimum. Indikator P1 memiliki tingkat kesukaran yang rendah, yaitu memiliki logit -1 yang artinya 11 peserta didik bisa memperoleh nilai tertinggi atau maksimum.

Berdasarkan Gambar 3, Gambar 4 dan Gambar 5 kita bisa simpulkan bahwa penerapan Siklus I memperoleh nilai psikomotorik yang sangat baik. Fenomena ini sejalan dengan Valia (2015: 368-369) yang menyatakan bahwa hasil belajar peserta didik mengalami peningkatan apabila adanya perbaikan pada model dan strategi pembelajaran.

\section{SIMPULAN DAN SARAN}

Berdasarkan hasil penelitian dan pembahasan, hasil belajar peserta didik kelas XI IPA SMA Advent Manokwari pada materi fluida dinamis mengalami peningkatan setelah dilakukan penerapan model kooperatif tipe SAVI. Hal ini didukung dengan temuan bahwa peningkatan hasil belajar peserta didik setelah menggunakan model kooperatif tipe SAVI, ketuntasan hasil belajar kognitif peserta didik pada siklus I sebesar 83 dan siklus II sebesar 88 . Peningkatan hasil belajar psikomotorik peserta didik pada siklus I sebesar 93 dan siklus II sebesar 94.

Berdasarkan hasil penelitian, maka peneliti memberikan saran bahwa penerapan model kooperatif tipe SAVI dapat meningkatkan hasil belajar peserta didik, sehingga dalam proses pembelajaran berlangsung guru diharapkan untuk menerapkan model kooperatif tipe SAVI. Bagi peneliti lainnya yang ingin mencoba model ini, diharapkan untuk melakukan penelitian terhadap kreativitas peserta didik.

\section{DAFTAR PUSTAKA}

Armawati., S., A., \& Azis, A. (2014). Penerapan Model Pembelajaran SAVI (Somatic,Auditory, Visual dan Intellectual) dapat Meningkat Hasil Belajar Peserta Didik Kelas VII.A SMP Aisyiyah Sungguminasa. JPS, 3 (2), 117-122.

Fitriyaningsih, J., Rahardjo, T., \& Dwi. (2013). Penerapan Pendekatan Somatic, Auditory, Visual, Intellectual (SAVI) untuk Meningkatkan Motivasi dan Hasil Belajar Fisika Siswa Kelas XI di SMA Negeri 3 Boyolali Tahun Pelajaran 2012/2013. Jurnal Pendidikan Fisika, 2 (2), 30-34.

Hamid, A., A. (2011). Apa dan Bagaimana Pendekatan Generik dan Metode Iqra Dilaksanakan dalam Pembelajaran Fisika. Yogyakarta: Universitas Negeri Yogyakarta.

Handayani, T., Mujasam, Widyaningsih S. W., \& Yusuf I. (2017). Penerapan Model Pembelajaran Kooperatif Tipe Snowball Throwing Terhadap Hasil Belajar Peserta Didik. Jurnal Curricula, 2(1), 47-58.

Jamal, A. (2013). Meningkatkan Hasil Belajar Siswa Kelas XI IPA-1 SMA Negeri 1 Jorong Melalui Pembelajaran Kooperatif Tipe Somatic Auditory Visual and Intellectual pada Pokok Bahasan Impuls dan Momentum. Jurnal Berkala Ilmiah Pendidikan Fisika, 1 (2), 159-168.

Lesmono. (2012). Metode Praktikum dalam Pembelajaran Pengantar Fisika SMA. Jurnal Pembelajaran Fisika, 1 (3), 285-289.

Pamelang., Yuani., Febrina. \& Wahyudi. (2012). Peningkatan Minat Belajar dan Hasil Belajar Matematika Melalui Pembelajaran Matematika Realistik (PMR) pada Siswa Kelas 4 SD Negeri Ledok 04 Kecamatan Argomulyo Kota Salatiga Semester 2 Tahun Pelajaran 2012/2013. Skripsi, Universitas Kristen Satya Wacana. 
Pratama, E, H. (2015). Keterampilan Proses Sains Siswa Jurusan IPA Beberapa SMA di Yogyakarta. Skripsi, Universitas Sanata Dharma

Riduwan. (2011). Skala Pengukuran Variabel-variabel Penelitian. Bandung: Alfabeta.

Sumintono, B., \& Widhiarso, W. (2015). Aplikasi Model Rasch untuk Penelitian Ilmu Sosial. Cimahi: Trim Komunikata.

Sumintono, B., \& Widhiarso, W. (2015). Aplikasi Pemodelan Rasch pada Assessment Pendidikan. Cimahi: Trim Komunikata.

Sari, P. I., \& Setyaningtyas, W. E. (2015). Peningkatan Hasil Belajar IPA Siswa Kelas V dengan Model Problem Solving Dipadukan dengan Metode NHT. Jurnal Mitra Pendidikan. 1 (5), 562.

Suarjana, M., Suwatra., \& Redika, G. I. (2014). Implementasi Model Pembelajaran SAVI (Somatis, Auditori, Visual, Intelektual) untuk Meningkatkan Hasil Belajar Matematika Siswa Kelas V SD. Junal Mimbar PGSD, 2 (1), 1-11

Sari, W., A. R, M., \& Melvina. (2017). Pengaruh Pendekatan Savi (Somatic, Auditory, Visual, And Intellectual) dengan Menggunakan Media Education Card Terhadap Pemahaman Siswa. Jurnal Ilmiah Mahasiswa (JIM) Pendidikan Fisika, 1 (4), 108-113.

Valia, R., Sudiyanto., \& Ivada, E. (2015). Model Pembelajaran Kooperatif Kombinasi Peer Tutoring dan Teams Games Tournament pada Pembelajaran Akuntansi. Jurnal Tata Arta. 1 (3), 361-370.

Wijayanti, F. T., Prayitno, A. B., \& Marjono. (2013). Pengaruh Pendekatan SAVI Melalui Model Pembelajaran Kooperatif tipe STAD Terhadap Hasil Belajar pada Siswa Kelas VII SMP Negeri 14 Surakarta. Pendidikan Biologi, 5 (2), 1-14 